\title{
Reduction of Write Field with Enhanced Write Margin in Toggle MRAMs Using Induced Spin-flop Mode
}

\author{
Y. Fukumoto, C. Igarashi, and T. Suzuki \\ System Devices Research Laboratories, NEC Corporation, 1120 Shimokuzawa, Sagamihara, Kanagawa 229-1198, Japan
}

Free layer structures, where two soft magnetic layers were ferromagnetically coupled with a synthetic antiferromagnet (SAF) through non-magnetic layers, were demonstrated to freely control the spin-flop field $\left(H_{\text {flop }}\right)$ and the saturation field $\left(H_{s}\right)$ of $0.32-\mu m$-wide magnetic tunnel junctions in toggle magnetoresistive random access memories (MRAMs). In the free layer, by reducing the coupling strength through the non-magnetic layers, the magnetization reversal of each soft magnetic layer induced a spin flop of the SAF at a lower field (called the "induced spin-flop mode"), resulting in an $H_{\text {flop }}$ reduction. The $H_{S}$ was significantly increased while maintaining a low $H_{\text {flop }}$ by replacing the bilayer SAF with a multilayer SAF. The free layers using the induced spin-flop mode are expected to reduce the write field of toggle MRAMs with densities greater than $4 \mathrm{Mb}$ to less than $50 \mathrm{Oe}$.

Key words: toggle MRAM, synthetic antiferromagnet, ferromagnetic coupling, spin flop, Mbit, write field

\section{誘導スピンフロップモードを用いた toggle MRAM の 書き込み磁場の低減及び書き込みマージンの増大}

\author{
福本 能之・五十嵐 忠二・鈴木 哲広 \\ N E Cシステムデバイス研究所，神奈川県相模原市下九沢 1120（干229-1198）
}

\section{1. はじめに}

MRAM (magnetoresistive random access memory) は高速 $\mathrm{read} / \mathrm{write}$, 書き換え回数無限大の長所を持つ不揮発性磁気メモリ である. 高 MR 比を示す MTJ (magnetic tunnel junction) カ報告 され ${ }^{1)}$, bit 選択書き込みは bit 線/word 線に電流を流して誘起され る磁場と, 強磁性体の astroid スイッチング特性を利用する事によ り read/write 方法か確立され，IBM が MTJ を使用した MRAM 開発を始めてから 2) 多くの企業か研究開発を行ってきた。 ほぼ 10 年か経ようとしている今，astroid MRAM に関して 16 Mbit の容 量を持つ MRAM 試作発表はあるものの 3),4)，未だ製品化にまで至 つた所はない，一方 bit 書き込み選択性に優れた toggle 書き込み 方式を使用した toggle MRAMがFreescaleから発表され5)，2006 年7月に $4 \mathrm{Mbit}$ の容量で製品化されている. MRAMにおいて書 き込み選択性の確保は重要である. Fig. 1, Fig. 2 に astroid/toggle MRAM の bit 線/word 線磁場に対する bit 書き込み歩留まりのマ ップをそれぞれ示す。太線で示される平均反転磁場 $\left(H_{S W}\right)$ 閾值曲 線から, 点線と矢印で示されるアレイサイズや bit 特性ばらつきに 応じたばらつき幅を考慮して書き込み磁場領域が決定される。 write region (斜線のエリア) が 100\%書き込める選択書き込み領 域であり, no switching で示されるエリアが全く書き込みされな い領域である.アレイサイズや $H_{S W}$ ばらつきが大きくなるほど書 き込み磁場は増大し，書き込み領域は減少する。

MRAM の用途を広げるには大容量化が重要となる. その為には 書き込み電流源とセルへの電流選択回路を小さくしてセル占有率 を上げることが必要となるが，その際トランジス夕の小型化によ り大電流をセルへ流せなくなる，例えば，我々のグループか試作

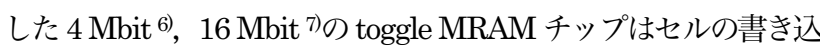
み電流值を約 $10 \mathrm{~mA}$ に収女なければならない,さらに容量を 64 Mbit 以上に上げる為には，セルサイズを低減しつつ書き込み電流 を数 $\mathrm{mA}$ に低減することが必要である．配線磁場は配線幅の逆数
に比例する為 MTJ 幅が小さいほど有利となるが， $H_{\text {SW }}$ は形状磁気 異方性の為に増大する，従って $H_{S W}$ を低減し書き込夕磁場を低減 する事が必須となる。

astroid/toggle MRAM の問題として, 書き込み磁場の低減と書 き込み選択性の確保の両立力灘しいことが挙げられる．Fig. 1(a) に示される astroid MRAM では $H_{S W}$ は異方性磁場 $\left(H_{k}\right)$ に比例し,

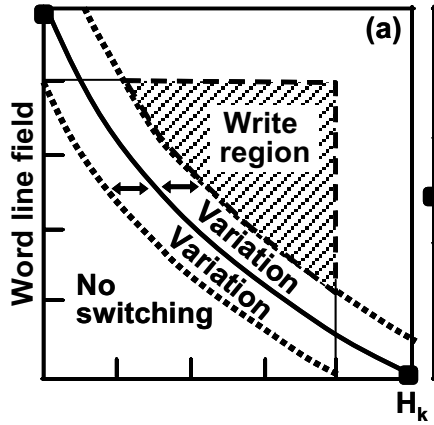

Bit line field

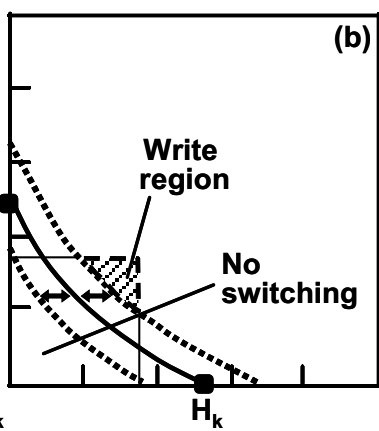

Bit line field
Fig. 1 Write yield maps for bit line and word line fields in astroid MRAMs (a) before and (b) after reduction of the switching field.
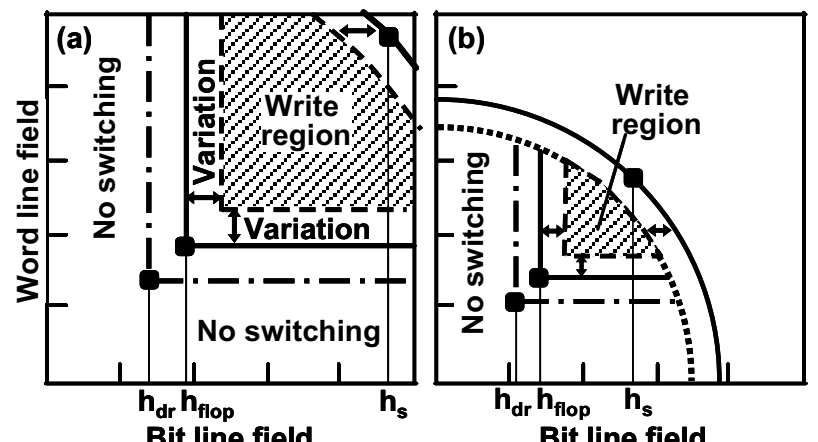

Fig. 2 Write yield maps for bit line and word line fields in toggle MRAMs (a) before and (b) after reduction of the switching field. 


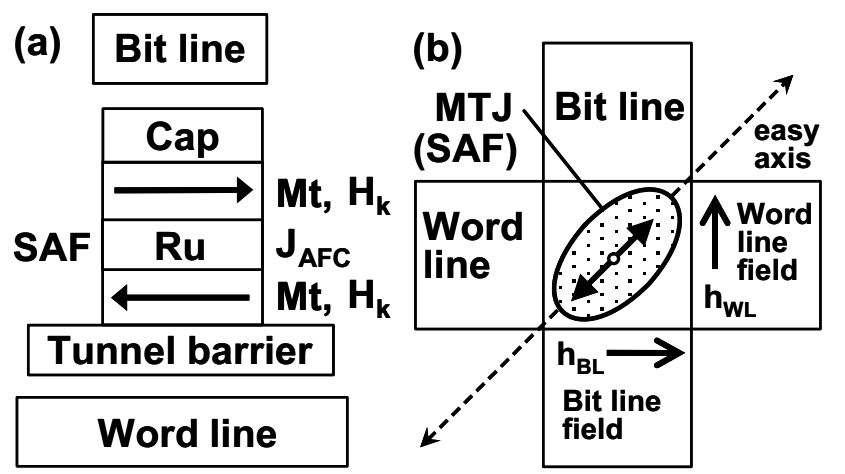

Fig. 3 (a) Cross-sectional view and (b) top view of the cell structure of toggle MRAMs. An SAF free layer is used.
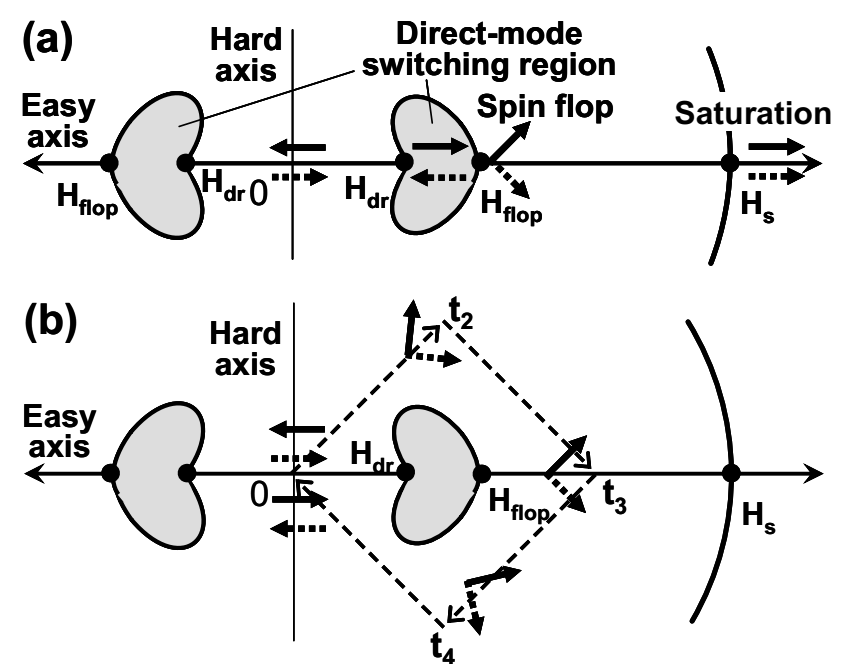

Fig. 4 Critical curves (bold line) of the direct-mode switching region (gray) and the saturation field of SAFs. The magnetic configuration is shown at each field in cases of (a) applied fields along the easy axis and (b) toggle write as shown in Fig. 5.

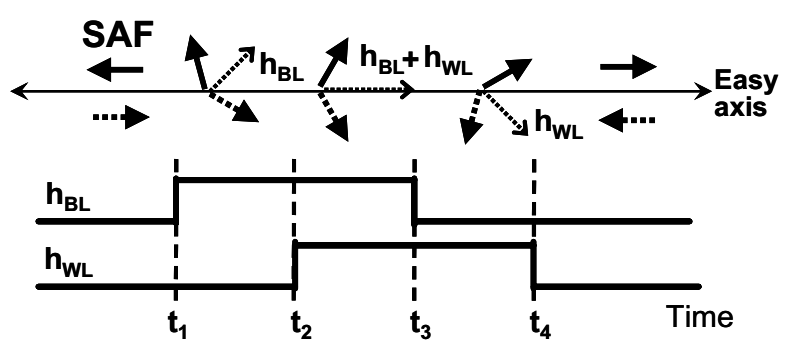

Fig. 5 Schematic of the toggle-write sequence. Generation timing of the bit line and word line fields and corresponding magnetic configurations of the SAF are shown.

書き込みマージンも同時に決定される. 問題は $H_{S W}$ ばらつきに対 する書き込信頼性の確保か灘しいことである。どちらかの書き 込み線のみからの磁場が加わつた状態で書き込まれてしまう bit が発生し (半選択誤書き込み), 選択書き込み領域か狭い. Fig. 1(b) に $H_{S W}$ 低減後の典型的な書き込みマップを示す． $H_{k}$ を減少させれ ば $H_{S W}$ は容易に下がるが， $H_{S W}$ ばらつき低減には限界がある為選 択書き込みマージンの確保がますます難しくなる. 一方 Fig. 2(a)
で明らかなように, toggle MRAM は半選択誤書き込みを起こしに くく, 選択書き込み領域も広く, $H_{S W}$ ばらつきに対し書き込み信頼 性を確保し易い. ここでスピンフロップ磁場 $\left(H_{f f o p}\right)$ が $H_{s W}$ に相当 し, $H_{f l o p}$ から飽和磁場 $\left(H_{s}\right)$ までの磁場範囲 $H_{S}-H_{f l o p}$ が書き込み マージンに相当する. Fig. 2 の $h_{\text {flop }}$ 及び $h_{s}$ は, $H_{\text {flop }}$ 及び $H_{s}$ の $45^{\circ}$ 方向成分である $\left(H_{f l o p}=\sqrt{2} h_{\text {flop }}, H_{s}=\sqrt{2} h_{s}\right)$. Fig. 2(b) に toggle MRAM の $H_{S W}$ 低減後の典型的な書き込みマップを示す. $H_{f l o p}$ を低減するには $H_{k}$ 及び $H_{s}$ を大きく低減しなければならず書 き込みマージンが減少するため, astroid MRAM と比較すると低 い $H_{S W}$ を得ることか灘しい.

新しい書き込み方式としてスピントルク磁化反転を利用した 4 kbit MRAM が試作されている8). 高い書き込み選択性と $1 \mathrm{~mA}$ 以 下の低書き込み電流值が実現されるものの, 代わりに read/write 操作時の相互ディスターブとトンネルバリアの絶縁破壊問題が生 じる. また現状は素子短辺長か約 $100 \mathrm{~nm}$ と非常に小さいセル, 且つ低い熱擾乱耐性の下での動作報告があるのみで, リソグラフ イの形状ばらつきに起因した write 電流/read 抵抗のばらつきの増 大や熱擾乱而性など, 大容量 MRAM チップで良品を得るに至る までに解決しなければならない課題が多い.

大容量 MRAM を早期に実現することは MRAM 市場を確立す る上で重要であり, 現状は read/write 両方の信頼性を確保できる toggle MRAM が有望である. その書き込み磁場が高いという問題 の解決はキーとなる.これまでの toggle MRAM の書き込み磁場 低減方法として, アンバランスな SAF 固定層からの漏孔磁場によ る $H_{\text {flop }}$ の零磁場へのシフト 9, 10), 11), SAF 自由層中の反平行結合へ の強磁性的結合成分の付与 11, 12) か報告されている. しかしながら, ばらつきを含めた書き込みマージンと書き込み磁場值の観点から Mbit 容量に適用可能な toggle MRAM セル技術の報告は未だにな い. 本論文では, $0.32 \mu \mathrm{m}$ 幅のMTJにおいて, Mbit容量のMRAM アレイに適用可能な toggle セル開発を行った. 4 Mbit で予想さ れる書き込みマージンを確保し，ヨーク配線 13)，14)を使用して書き 込み電流值を $10 \mathrm{~mA}$ 以下に低減する事が可能となるように, 書き 込久磁場を $50 \mathrm{Oe}$ 以下に低減する事を目標として開発を行った。

\section{2. toggle MRAM の動作原理}

toggle MRAM は free 層として, 二つの強螆性層が反平行に結 合した SAF (synthetic antiferromagnet) で磁化の差が零である ものが使用される. Fig. 3(a)(b)に toggle MRAM セルの断面図と 平面図をそれぞれ示す。配線磁場 $(h B L, h w L)$ 方向は SAF 容易軸 に対して $45^{\circ}$ 方向に設定される. Fig. 4(a)に外部磁場に対する SAF 各反転モードの閾值曲線と磁化配置の図を示す.SAF に対して零 磁場から容易軸方向へ磁場を印加していくと, ダイレクト反転磁 場 $\left(H_{d l}\right)$ において反平行結合を保つたまま容易軸のどちらかの方 向に反転する.グレーで示されたダイレクト反転領域を抜けた $H_{\text {flop }}$ において, 二つの強磁性層の合成磁化方向と磁場方向が一致 するように，二つの磁化が開いた状態に再配置する（スピンフロ ップ). さらに $H_{s}$ において二つの強磁性層は平行配置となる. SAF がスピンフロップした磁化配置において, 時系列的に bit 線/word 線磁場を印加して toggle 書き込みを行うことができる (Fig. 5). Fig. 4(a)に示した磁化状態の閾值曲線のマップ上で, Fig. 5 の 
toggle 書き込みに対応したものを Fig. 4(b)に示す。 toggle 書き込 みはダイレクト反転領域を周るように状態が遷移する ${ }^{15)}$. SAF 膜 の $H_{s}$ 及び $H_{f l o p}{ }^{15)}$, 書き込みマージン $H_{s}-H_{f o p}$ は以下で表される.

$$
\begin{aligned}
& H_{\mathrm{s}}=2 J_{A F C} / M t-H_{\mathrm{k}} \\
& H_{\text {flop }}=\left\{H_{k}\left(2 J_{A F C} / M t+H_{k}\right)\right\}^{0.5} \sim\left(H_{k} H_{s}\right)^{0.5} \\
& H_{\mathrm{s}}-H_{\text {flop }} \sim H_{\text {flop }}\left\{\left(2 J_{\mathrm{AFC}} /\left(H_{\mathrm{k}} M t\right)-1\right)^{0.5}-1\right\}
\end{aligned}
$$

$M t$ は各強磁性層の磁化と磁気膜厚の積, $J_{A F C}$ は反平行結合工ネ ルギーである.

\section{3. 実験方法}

試料は熱酸化膜付 8 インチ $\mathrm{Si}$ 基板上に DC マグネトロンスパッ 夕により成膜した. MTJ膜構成は基板 $/ \mathrm{Ta}(200 \AA) / \mathrm{NiFe}(10 \AA)$ $/ \mathrm{PtMn}(200 \AA) / \mathrm{Cog}_{0} \mathrm{Fe}_{10}(20 \AA) / \mathrm{Ru}(9 \AA ̊) / \mathrm{Cog}_{0} \mathrm{Fe}_{10}(20 \AA) / \mathrm{Al}(8.6 \AA) \mathrm{O} /$ free 層/Al(6.4Å)O/Ta である. トンネルバリア及び cap 層の $\mathrm{AlO}$ は $\mathrm{Al}$ をラジカル酸化することによって形成した. free 層の上下界 面が共通であることで, 両端界面のデッドレイヤーも同程度とな り free 層内の残留磁化を低減できること, 磁気特性の耐熱性向上 などの利点がある 16). 反平行結合のスペーサー層は耐熱性の観点 から厚い $\mathrm{Ru}(20 \AA ̊)$ の, 弱い反平行結合のピークを使用した. free 層膜構成は次のとおりである.

S1： $\mathrm{NiFe}(30 \AA) / \mathrm{Cog}_{0} \mathrm{Fe}_{10}\left(d_{C o F e}\right) / \mathrm{Ru}(20 \AA) / \mathrm{Cog}_{0} \mathrm{Fe}_{10}\left(d_{C o F}\right)$

$/ \mathrm{NiFe}(30 \AA) \quad d_{C o F e}=3.5,5 \AA$

S2: $\mathrm{NiFe}(30 \AA ̊) / \mathrm{Cog} 0 \mathrm{Fe}_{10}(3.5 \AA) / \mathrm{Ru}(20 \AA ̊) / \mathrm{NiFe}(37 \AA)$

S3: $\mathrm{NiFe}(d) / \mathrm{NM} / \mathrm{NiFe}($ d)/Ru$(20 \AA) / \mathrm{NiFe}($ d)/ NM $/ \mathrm{NiFe}(d)$ $\mathrm{NM}$ は非磁性層であり, 本論文では超薄膜の $\mathrm{Ta}\left(d_{T a}\right)$ または Ru/Ta である. $\mathrm{NM}$ は外側の $\mathrm{NiFe}(d)$ と内側の $\mathrm{NiFe}(d)$ との強磁性結合力 を制御し，下部の NM はその上に成長させる $\mathrm{NiFe} / \mathrm{Ru}$ 層の $\mathrm{NiFe}(111) / \mathrm{Ru}(001)$ 配向を促進し, 十分な $J_{A F C}$ を発現させる役割を 果たしている. $d$ は各 $\mathrm{NiFe}$ 層の成膜厚である. Ta 厚の増加に対 して $\mathrm{NiFe} / \mathrm{Ta}$ 界面にデッドレイヤーが形成されるため, 各 $\mathrm{NiFe}$ 層の磁化膜厚積が等しく $1.3 \mathrm{Tnm}$ となるように, $d$ を $20 \AA$ から $25 \AA$ まで増加させている. また $\mathrm{S} 1, \mathrm{~S} 2$ は $\mathrm{CoFe}$ の Ru界面への挿 入によって大きな $J_{A F C}$ を発現し $H_{S}$ を増大している構成の $\mathrm{SAF} て ゙$ ある. $0.24 \mu \mathrm{m}$ ルールのリソグラフィとイオンミリングを用いて 短軸が $0.32 \mu \mathrm{m}$ ，長軸が $0.96 \mu \mathrm{m}$ の棈円 MTJを作製した．MTJ は加工前と加工後に磁場中熱処理を行った. 条件は $1.2 \mathrm{~T}$ の磁場中 で $275^{\circ} \mathrm{C}, 5$ 時間である. 評価に関して, 磁化曲線は振動式磁力計

(VSM) によって測定した. toggle 書き込みは直流四端子法，2 軸の電磁石コイルにより toggle 書き込みの磁場シーケンス(Fig. 5) を印加して行った。磁場は容易軸に対して 45 度方向に印加されて いる. 8 インチ基板全面より合計 120 個を測定し, 平均 $H_{f l o p,} H_{s,}$ $H_{d r}$ 及びそれらのばらつきである標潐偏差( $($ )を得た。

\section{4. 実験結果}

\section{1 free 層 S3 の MTJ 膜における磁気特性}

S3 $\left[\mathrm{NM}=\mathrm{Ta}\left(d_{T 2}\right)\right]$ の膜での $H_{\text {flop }}$ 及び $H_{s}$ を調べる為, S3 を free 層に持つ MTJ 膜の磁化曲線を測定した. Fig. 6 は, 横軸に Ta 厚, 縦軸に(a) $H_{f o p}$ 及び(b) $H_{s}$ さらに(c)に式(2)より見積もられる $H_{k}=$
$H_{\text {flop }}{ }^{2} / H_{s}$ の值と $\mathrm{Ta} / \mathrm{AlO} / \mathrm{NiFe}(\mathrm{d}) / \mathrm{Ta}\left(\mathrm{d}_{\mathrm{Ta}}\right) / \mathrm{NiFe}(\mathrm{d}) / \mathrm{Ru}$ 強磁性結合膜 の困難軸方向の磁化曲線より得られた膜固有の $H_{k}$ を示している. (d)に S3 中の NM の Ta を介した強磁性結合力（強磁性結合工ネ ルギー： $J_{F C}$ ）の值を示す. $J_{F C}$ は次のように見積もった。基板 $/ \mathrm{Ta}(50 \AA) / \mathrm{Ru}(30 \AA) / \mathrm{IrMn}(200 \AA) / \mathrm{CoFe}(15 \AA) / \mathrm{NiFe}(20 \AA) / \mathrm{Ta}\left(\mathrm{d}_{\mathrm{Ta}}\right) / \mathrm{Ni}$ $\mathrm{Fe}(40 \AA) / \mathrm{Ru}$ 積層膜の磁化曲線を測定する. $d$ 加増大するにつれ て $\mathrm{IrMn} / \mathrm{CoFe}(15 \AA) / \mathrm{NiFe}(20 \AA ̊)$ の交換バイアス膜と $\mathrm{NiFe}(40 \AA)$ に 起因した磁化曲線が分離していき 2 段のヒステリシス曲線か明膫 になる. $\mathrm{IrMn} / \mathrm{CoFe}(15 \AA) / \mathrm{NiFe}(20 \AA)$ の交換バイアス膜が, $J_{F C}$ の 大きさで $\mathrm{NiFe}(40 \AA)$ と強磁性結合をしているモデルを仮定し, こ れらのヒステリシス曲線を、4.1 節で後述する計算方法と同様 の一斉回転モデルで、 $J_{F C}$ をパラメーターとしてフィッティング した. Fig. 6(a)(b)において, Ta 厚の増加に対して $d_{7 a} \leq 4 \AA$ の範囲 では $H_{s}$ 及び $H_{f l o p}$ が共に増大していく.これは極薄 $\mathrm{Ta}$ 上の $\mathrm{NiFe}(111) / \mathrm{Ru}(001)$ 配向が向上するためである ${ }^{17)}$ ） その結果 $J_{A F C}$ そして $H_{s}$ が増大し, 式(2)に従って $H_{\text {flop }}$ か増大したものと考えら れる. しかしながら $d_{T a}>4 \AA$ では $H_{S}$ がさらに増大していくのに対 して， $H_{\text {flop }}$ は減少に転ずる. これは式(2)では説明できない. また Fig. 6(c)の $H_{k}$ に関しても, $d T_{a} \leq 4 \AA$ では見積もり值は膜固有の $H_{k}$ よりもやや高い.これは MTJ 膜中の SAFでは, バリアを介した 固定層からのネール結合の寄与で $H_{\text {flop }}$ が若干増大し ${ }^{18)}$, 特に $H_{s}$ が小さくなる程 $H_{\text {flop }}$ 増大効果か現れ, $H_{k}$ 見積もり值か増大したも のと考えられる. しかしながら $d_{T a}>4 \AA$ でで膜固有の $H_{k}$ がほぼ 一定であるのに対して見積もり值は $0.5 \mathrm{Oe}$ まで極端に減少してい く. S3 の膜固有の $H_{k}$ とネール結合からの寄与の和は少なくとも 3

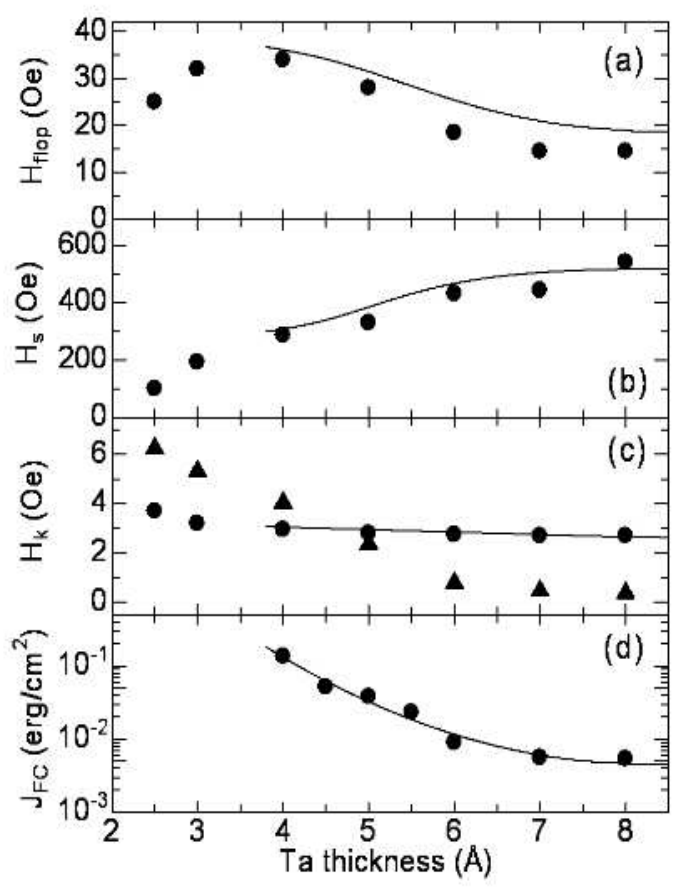

Fig. 6 (a) Spin-flop field, (b) saturation field, (c) anisotropy fields of measured values (circles) and estimated values of $H_{\text {flop }}{ }^{2} / H_{S}$ (triangles), and (d) ferromagnetic coupling strength through the Ta layer of the S3 films. The solid lines in Figs. 3(a) and (b) are the calculated results using Eqs. (4) and (5) (assuming $J_{A F C}=0.029 \mathrm{erg} / \mathrm{cm}^{2}, M t=1.3$ Tnm). 


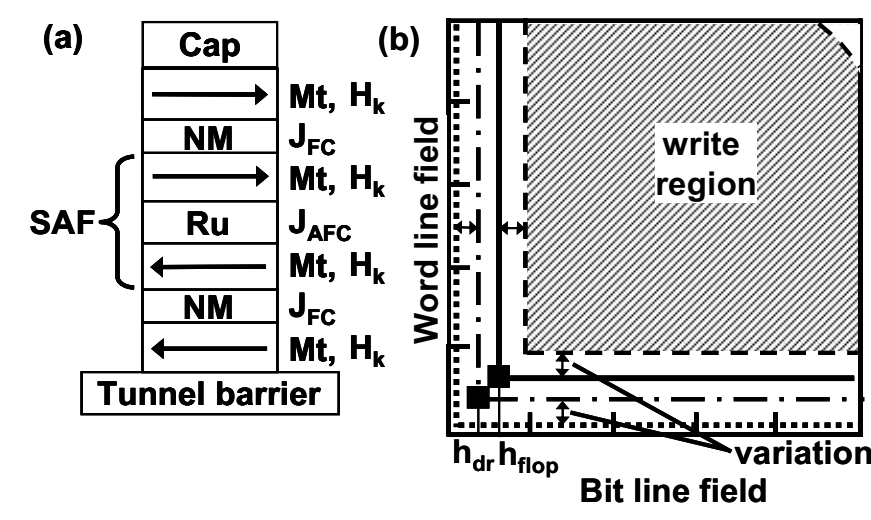

Fig. 7 (a) Magnetic structure of MRAM cells using induced spin-flop mode and (b) write yield map of toggle MRAMs using these cells.

Oe 以上であるはずなので, 式(2)では $d_{T a}>4 \AA$ の $H_{k}$ を説明でき ない. Fig. 6(d)より, $d T a>4 \AA$ では, $J_{F C}$ は Ta の増大に伴い指 数的に急減少し, やがて緩やかな減少に変わる。これは不連続で あつた極薄 $\mathrm{Ta}$ 層が連続膜となり，上下 $\mathrm{NiFe}$ 層同士の交換相互作 用による強磁性結合を分断し, やがて $\mathrm{NiFe}$ 界面の凹凸の磁極を介 したネール結合的な強磁性結合に変わったものと考えられる.こ のように J J $F$ が大幅に弱められた場合, $\mathrm{NiFe} / \mathrm{Ta} / \mathrm{NiFe}$ 層は一体の 磁性層とは見なせず, Fig. 7(a)に示される磁気構造を考えなければ ならない. この”反転誘導 toggle セル”の $H_{\text {flop }}$ 及び $H_{s}$ は, 一斉回転 モデルを仮定し静磁結合を考慮しない場合において, 4つの強磁性 層のゼーマンエネルギー, 異方性エネルギー, 隣接した強磁性層 間の平行/反平行結合エネルギーの和の磁化角度に関する 2 階微 分から, 安定点が不安定点に遷移する磁場を求めることによって, 次式のように計算される ${ }^{19)}$.

$H_{\mathrm{s}}=\left\{1-b+\left(1+b^{2}\right)^{0.5}\right\}\left(J_{\mathrm{AFC}} / M t\right)-H_{\mathrm{k}}$

$H_{\text {flop }}=\left[H_{\mathrm{k}}^{2}+(1+2 b) H_{\mathrm{k}}\left(J_{\mathrm{AFC}} / M t\right)+b(1+2 b) H_{\mathrm{k}}\left(J_{\mathrm{AFC}} /\right.\right.$ $M t)^{2}-\left(J_{\mathrm{AFC}} / M t\right)\left\{b^{2}(1+2 b)^{2}\left(J_{\mathrm{AFC}} / M t\right)^{2}+2 b(1+2 b+\right.$ $\left.\left.\left.4 b^{2}\right) H_{\mathrm{k}}\left(J_{\mathrm{AFC}} / M t\right)+\left(1+4 b^{2}\right) H_{\mathrm{k}}{ }^{2}\right\}^{0.5}\right]^{0.5}$

$b=J_{\mathrm{FC}} / J_{\mathrm{AFC}}$

$\mathrm{NiFe} / \mathrm{Ru} / \mathrm{NiFe}$ から構成される内側の $\mathrm{SAF}$ に対して外側の $\mathrm{NiFe}$ 層が $J_{F C}$ の大きさで緩く結合している為, 外部嗞場が $\mathrm{NiFe}$ 本来の $H_{s W}$ 以上になると, 磁場に対して反対側を向い ている外側の $\mathrm{NiFe}$ 層が磁化反転しょうとする。 その際に 内側の SAF のスピンフロップを誘導する ${ }^{20)}$. その結果低 磁場でスピンフロップさせることができる. また高磁場で は内側の SAF 本来の $H_{s}$ 近くまで磁化飽和しにくくなる.

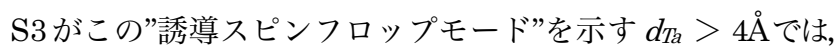
Ref.20 の Fig.3(b)に示されるように, 外部磁場の増大に対 して常に外側の $\mathrm{NiFe}$ 層が磁場方向へ先行して回転し, 内 側の SAF の磁化は遅れて追随する計算結果が得られてい る. $J_{A F C}=0.029 \mathrm{erg} / \mathrm{cm}^{2}{ }^{17)}, M t=1.3 \mathrm{Tnm}$, Fig. $6(\mathrm{c})(\mathrm{d})$ に示されている $H_{k}$ 及び $J_{F C}$ の実測值をフィッティングした 連続デー夕を使用して, 式(4)(5)から得られた $H_{\text {flop }}$ 及び $H_{s}$
を Fig. 6(a)(b)中に実線で示す。 $J_{F C}$ を低減するほど $H_{f l o p}$ は 減少 $H_{S}$ は増大し, 実験データと良い一致を示している。こ れは書き込み磁場の減少と書き込みマージンの増大が同時 に実現されることを意味し，これにより 4.3 節で後述する ように Fig. 7(b)に示される書き込みマップを得ることが可

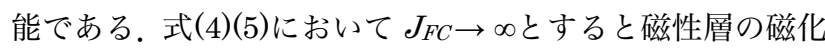
膜厚積が $2 M t$ の通常スピンフロップモードの式(1)(2)に一 致し, 各 $\mathrm{NiFe}$ 層が一体となってスピンフロップすること を意味する。また誘導スピンフロップモードの極限では $\left(J_{F C} \rightarrow 0\right), H_{f l o p}=H_{k}, H_{s}=2 J_{A F C} / M t-H_{k}$ に漸近し, この $H_{f l o p}$ は外側の $\mathrm{NiFe}$ 層本来の $H_{s w}, H_{s}$ は内側の $\mathrm{SAF}$ 本来の飽和磁場 $H_{S}$ 'にそれぞれ一致する。このとき外側の $\mathrm{NiFe}$ 層のみが内側の $\mathrm{SAF}$ のスピンフロップを誘導せずに 独立に反転しエラーとなる. 反転誘導 toggle セルではこの ようなエラーが生じない範囲で $J_{F C}$ を低減することで $H_{f l o p}$ を下げられるが, SAFのように書き込みマージンを大幅に 犠牲にしなくてもよい優位点がある.

\section{2 toggle セルの書き込み特性}

MTJセルでの $H_{f l o p}$ 低減開発を行った. まずfree 層が通常のSAF における結果を示す. 式(2)(3)から， $H_{\text {flop }}$ を下げて書き込みマージ ンを確保するには $H_{k}$ を可能な限り低減し $J_{A F C}$ を許容範囲内で低 減すれば良い. Fig. 8 下段に横軸に膜の磁化曲線から求めた $J_{A F C}$, 縦軸に書き込み配線方向の $h_{f o p}$ 及 び $h_{s}$ を示す. 対応する膜固有の $H_{k}$ を上段にそれぞれ示す。試料 $\mathrm{S} 1$ 及び $\mathrm{S} 2$ は $\mathrm{NiFe} / \mathrm{CoFe}$ で磁性 層が構成され, $\mathrm{Ru}$ 界面の $\mathrm{CoFe}$ 総量が多いほど $J_{A F C}$ か増大し $H_{S}$ か増大するが, $H_{k}$ も増大するため $H_{f l o p}$ も増大する. 一方 $\mathrm{S} 3$ の通 常スピンフロップモードである $d_{T a} \leq 4 \AA$ の試料は $H_{k}$ が 3 Oe 程 度であるため $h_{f l o p}$ が低く， $d_{T a}$ を薄くして $J_{A F C}$ を低減していくと hflopが 32 Oe まで下がるが, $h_{s}$ が 84 Oe と減少し書き込みマージ ンが不足してしまう. 通常スピンフロップモードでは $h_{\text {flop }}$ 低減と 書き込みマージン確保がトレードオフである為, $J_{A F C}$ で必要な $h_{S}$ を確保し $H_{k}$ を低減するのみでは $h_{f o p}$ を自由に低減できない.

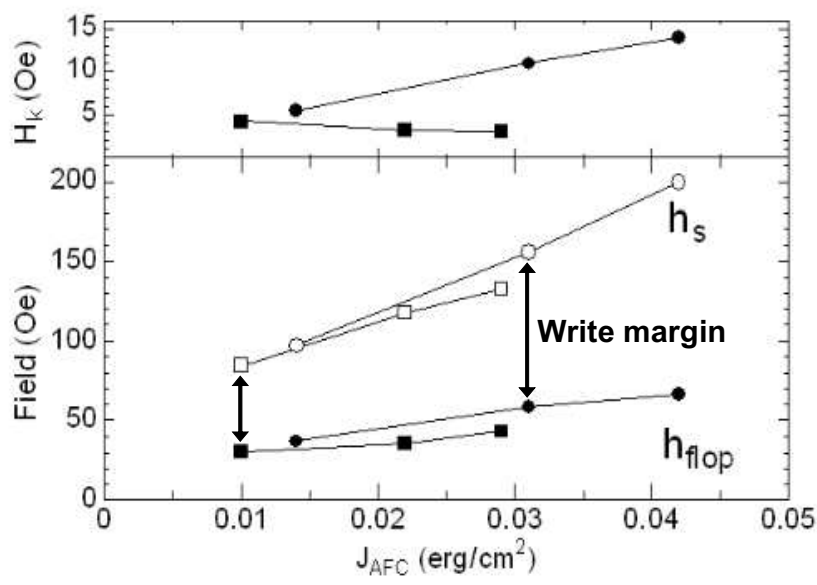

Fig. 8 Spin-flop field (closed symbols) and saturation field (open symbols) for the write line field as a function of the antiferromagnetic strength of the SAF in $0.32 \times$ $0.96 \mu^{2}$ MTJs showing normal spin-flop mode. The $H_{k}$ in the films for each data is plotted in the above figure. The data for $\mathrm{NiFe} / \mathrm{CoFe} \mathrm{SAF}$ (circles) and $\mathrm{NiFe} / \mathrm{Ta} / \mathrm{NiFe} \mathrm{SAF}$ (squares) are shown. 


\section{3 反転誘導 toggle セルの書き込み特性}

次に誘導スピンフロップモードによる $h_{f l o p}$ 低減結果を示す. Fig. 9(a)(b)に通常スピンフロップモードである S1 及び S2, Fig. 9(c)-(g)に誘導スピンフロップモードである S3 の hfop, $h_{s}$ の分布を 示す. (c)(d)は NM 層の材料を Ta，(e)-(f)は Ru/Ta としている. (g) は(e)とほぼ同一構造において, SAF 磁性層の数を倍である 4 層 $(4$ つの磁性層が反平行に結合した SAF) にしている. Fig. 9(e)(f)中 にはダイレクト反転磁場 $\left(h_{d r}\right)$ の分布も示している，各試料の書き 込み特性を Table 1 にまとめた. 表中の書き込み磁場/マージンに 関して，左側に 120bit 測定での実測值，右側に正規分布を仮定し

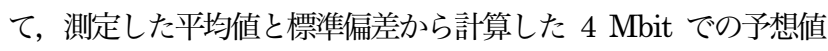
$(6 \sigma)$ を示した. free 層が SAFである $(\mathrm{a})(\mathrm{b})$ は $h_{\text {flop }}$ が大きくまた $h_{S}$ も小さく, それらのばらつき $\left(\sigma_{\text {flop }}\right.$ 及び $\left.\sigma_{s}\right)$ も大きい. その結果, 書き込み磁場が大きいにも関わらず 4〜128 Mbitの MRAM に必 要な $6 \sigma$ の書き込みマージン $\left(h_{s}-h_{\text {flop }}-6 \sigma_{f l o p}-6 \sigma_{s}\right)$ か確保できて いない. 一方 Fig. 9(c)-(g)では $h_{f l o p}$ 及び $h_{f l o p}$ ばらつきが小さく，そ の結果 $6 \sigma$ の書き込み磁場 $\left(h_{\text {flop }}+6 \sigma_{f l o p}\right)$ が50 Oe 以下で同時に書 き込みマージンも確保されている。 これらのセルは $4 \mathrm{Mbit}$ アレイ において書き込みマージンを保ちつつ書き込み電流值を $10 \mathrm{~mA}$ 以 下に下げることが可能と考えられる，以上は基板内分布の值であ り, アレイ内ではばらつきがさらに小さい為, 書き込み磁場も小 さくなることが予想される.

$H_{\text {flop }}$ を下げるには NM を介した強磁性結合を弱めること, 反転 誘導 toggle セル中の SAF 本来のスピンフロップ磁場 $H_{f l o p}$ ”を下げ ることが有効であり,この目的で $\mathrm{Ru} / \mathrm{Ta}$ を材料に検討した. $\mathrm{Ru} / \mathrm{Ta}$ を NM に用いた素子(e)(f)は, Ta を NM に用いた素子 Fig. 9 (c)(d) と比較して $h_{s}$ は若干小さいものの $h_{\text {ffop }}$ の值はより小さい. $\mathrm{Ru}$ は $\mathrm{Ta}$ と比較して同じ厚さの挿入に対して $J_{F C}$ を大幅に低減すること, また $\mathrm{Ru}$ は SAF の結晶配向を十分に促進しないため $J_{A F C}$ が小さい ことで $H_{s}{ }^{\prime}$ が下がり $H_{\text {flop }}$ 'が低減したことが原因と考えられる.

Fig. 9(e)に対して $J_{F C}$ を弱めた(f)は $h_{f l o p}$ が $14.4 \mathrm{Oe}$ と最も小さいが, 7 割以上の素子が書き込みできなかった。これらの素子の MR 曲 線は free 層の磁化か溶易軸から傾く抵抗変化が明膫に見られ, free 層はスピンフロップ動作を示していた. エラー原因として, Fig. 9(f)に示されるように, $h_{f l o p}$ が小さいため $h_{d r}$ も 8.1 Oe と小さく, その分布中の最小值はほぼゼロ付近まで下がっていることが考え られる. hdrが極端に小さくなると，Fig. 4(b)で有限の大きさを持 つダイレクト反転領域を toggle 書き込み中に回避できなくなり, 必ずダイレクト反転してしまう。これらの不良素子は $h_{d r}$ 起因の不 良と考えられる．また書き込むことができた素子も半選択状態か

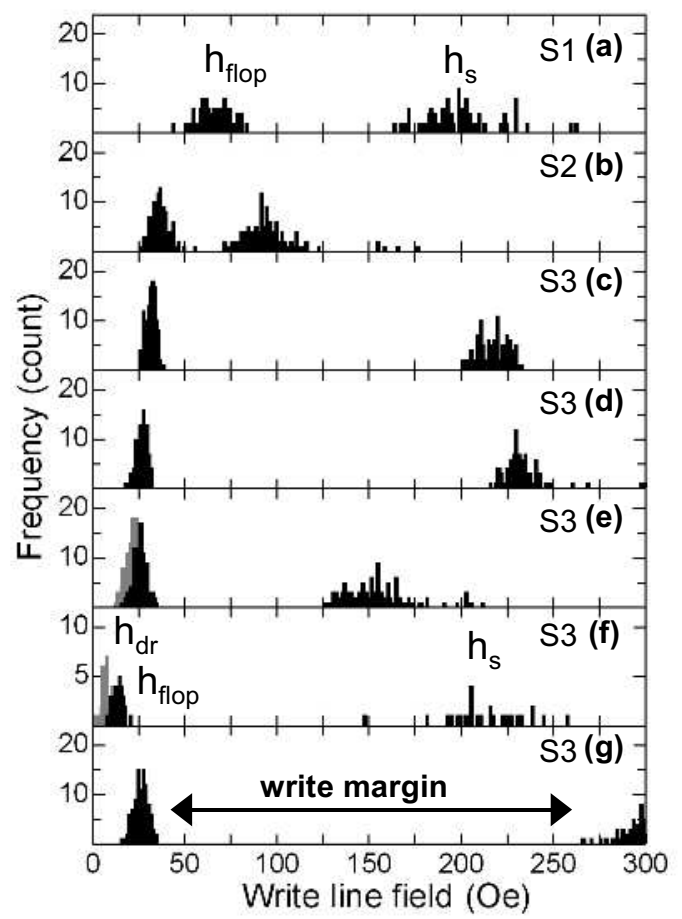

Fig. 9 Distributions of spin-flop field and saturation field in $0.32 \times 0.96 \mu^{2}$ MTJs as a function of write field. The distributions of the direct-mode switching field are shown as gray bars in (e) and (f).

らダイレクト反転領域に対するエネルギーバリアが小さく, 半選 択書き込み状態において確率的にダイレクト反転誤書き込み不良 を引き起こすため問題となる ${ }^{21)}$.

\section{4 多層 SAF を用いた反転誘導 toggle セル}

4.3 節で示されたように $H_{\text {flop }}$ を下げる手段として SAF の $H_{\text {flop }}$, を下げることが有効であるが $H_{S}$ も同時に下げてしまう.この問題 に対して SAFを多層化することが有効である. Fig. 9(e)の free 層 の SAFを 4 層化した Fig. $9(\mathrm{~g})$ は(e) と同等の低い $h_{f l o p}$ を保ったまま 2 倍の $h_{s}$ を示している.これは SAF を 4 層 SAF にしたことで $H_{\text {flop }}$ 'が一定のまま $H_{s}$ 'のみが増大し ${ }^{22)}$, さらに(e)の $H_{\text {flop }}$ ’同程 度の低 $H_{f l o p}$ ’を持つ 4 層 SAF に対する誘導スピンフロップによつ て(e) と同程度まで $h_{f l o p}$ が下がり， $h_{s}$ のみが増大したものと考えら れる. SAF 多層化と軟磁性層による誘導スピンフロップを組み合 わせることで独立に $h_{f l o p}$ を下げ， $h_{s}$ を増大させることが可能で, 更に磁気体積の増大により熱擾乱耐性が向上する ${ }^{23)}$. 反転誘導 toggle セルのスケーラビリテイが大きく改善される.

Table 1 Write properties of 120 MTJs using each free layer as in Fig. 9.

\begin{tabular}{|c|c|c|c|c|c|c|c|c|}
\hline Cell structure & $h_{\text {flop }}$ & $\sigma_{\text {flop }}$ & $\mathbf{h}_{\mathbf{s}}$ & $\sigma_{s}$ & $\mathbf{h}_{\mathrm{dr}}$ & Write field & Write margin & [120 bit / Mbit $(6 \sigma)]$ \\
\hline (a) $\mathrm{S} 1 \mathrm{~d}_{\mathrm{CoFe}}=5 \AA$ & 66.6 & 8.2 & 200 & 19.8 & & $85 / 116$ & $79 /-35$ & \\
\hline (b) S2 & 37.3 & 4.9 & 97 & 17.8 & & $57 / 67$ & $15 /-77$ & \\
\hline (c) $\mathrm{S} 3 \mathrm{NM}=\mathrm{Ta}(6 \AA)$ & 32.4 & 2.6 & 218 & 7.7 & & $37 / 48$ & $165 / 123$ & \\
\hline 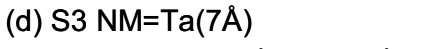 & 27.4 & 2.9 & 235 & 16.1 & & $33 / 45$ & $184 / 93$ & \\
\hline 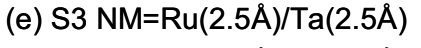 & 26.7 & 3.6 & 156 & 16.6 & 23.0 & $36 / 49$ & $96 / 8$ & \\
\hline 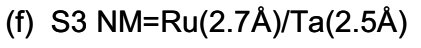 & 14.4 & & 214 & & 8.1 & & & \\
\hline (g) S3 NM=RuTa 4layer-SAF & 26.9 & 3.5 & 307 & 19.6 & & $36 / 48$ & $231 / 141$ & (unit: Oe) \\
\hline
\end{tabular}




\section{5 toggle 書き込み特性のばらつき原因}

各 free 層の $h_{\text {flop }}$ ばらつきについて考察する. Fig.10 に S2 $(\mathrm{NiFe} / \mathrm{CoFe} / \mathrm{Ru} / \mathrm{NiFe} \mathrm{SAF})$ 及び $\mathrm{S} 3[\mathrm{NM}=\mathrm{Ta}(6 \AA ̊))$ セルにおける bit 線/word 線磁場に対する $H_{f l o p}$ 值をプロットした. 配線磁場方向 の $h_{\text {flop }}\left[=\left(<h_{\text {flop }}(B L)>+<h_{\text {flop }}(W L)>\right) / 2\right]$ のばらつき, $H_{\text {flop }}[=$ $<\left\{h_{\text {flop }}(B L)^{2}+h_{\text {flop }}(W L)^{2}\right\}^{0.5}>$ ]のばらつきを図中の表にまとめた. Fig. 10 上で，前者は $H_{\text {flop }}$ 各点を bit 線/word 線に対して射影した 成分の平均ばらつき, 後者は原点から $H_{\text {flop }}$ 各点までの距離のばら つきに相当する. 前者が toggle 書き込み特性を決定する. Fig. 10 で S2 は S3 よりも容易軸方向に対する分散か特に大きいことがわ かる. その結果 $\mathrm{S} 2$ では容易軸方向に対する分散に鈍感である $H_{\text {flop }}$

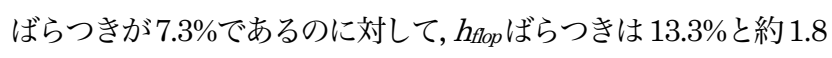
倍である. 更に S3 の $h_{f l o p}$ ばらつきと比較すると約 1.6 倍である. このばらつきの増大は $\mathrm{CoFe}$ による異方性分散の影響と考えられ る. また $\mathrm{S} 2$ は $\mathrm{S} 3$ よりも $H_{\text {flop }}$ が大きいのにも関わらず $H_{\text {flop }}$ ばら つきが大きい. 原因として大きな $J_{A F C}$ の発現か極溥 $\mathrm{CoFe}$ 挿入に 起因している $\mathrm{S} 2$ に対して, $\mathrm{Ru}(001)$ 高配向化に起因している S3 では, $J_{A F C}$ が一様であること, Ru 厚さに対する $J_{A F C}$ の発現範囲 が広いことにより ${ }^{17)}$ ，成膜 $\mathrm{Ru}$ 厚ばらつきの影響が小さい為と考 えられる. S3 の h hfopばらつきは他報告 18) と比較しても小さい. 更に Table 1 の $H_{s}$ ばらつきに関しても同じ理由で S3 は小さい.

今後の課題は, Fig. 7(b)に示されるように現状 $h_{f f o p}$ 低減を妨げて いるダイレクト反転領域の低減とその $H_{d r}$ ばらつきの低減, $H_{\text {flop }}$ ばらつきの更なる低減, 及び，熱擾乱而性の向上が挙げられる. 我々のグループでは書き込久電流值を $11 \mathrm{~mA}$ まで下げ ${ }^{14)}$, リ夕ン ダンシ救済によって $4 \mathrm{Mbit}$ 良品チップを得ており, ドライブレコ ーダーシステムをデモンストレーションしている ${ }^{6)}$, 24)。良品レベ ルの toggle MRAM チップ容量は未だ 4 Mbit ではあるが, 不揮発 性, 高速 read/write, 且つ書き換え回数無限大は他メモリにない 長所であり, 課題が解決され toggle MRAM の大容量化か実現さ れていくことでMRAM 市場か滩立されていくものと考えられる.

\section{5. まとめ}

書き込み磁場低減を目的として素子短辺長 $0.32 \mu \mathrm{m}$ の MTJで の toggle セル開発を行った，通常の toggle セルでは $H_{S}$ が急激に 減少するため十分に $H_{\text {flop }}$ を低減することができなかった，軟磁性 層を SAF と強磁性結合させた反転誘導 toggle セルでは, 強磁性結 合力を弱めるほど $H_{f l o p}$ が低減し $H_{s}$ が増大した. その結果書き込み マージンを保ったまま, ダイレクト反転によるエラーが許す範囲 で自由に $H_{\text {flop }}$ を低減することができた， SAF を多層化すること で低い $H_{\text {flop }}$ を保ったまま $H_{s}$ が大幅に延伸され， $H_{s}$ 及び $H_{\text {flop }}$ を独 立して制御可能であることが示された. SAF 中の Ru を(001)高配 向化すること, 磁性層から $\mathrm{CoFe}$ を除くことで $H_{\text {flop }}$ ばらつきが低 減された. 高い $H_{s}$ と低い $H_{\text {flop }}$, 低い $H_{\text {flop }}$ ばらつきと $H_{s}$ ばらつき によって, 4 Mbit MRAM での書き込みマージンを確保しつつ, 想定書き込み磁場 $\left(h_{\text {flop }}+6 \sigma_{\text {flop }}\right)$ が 50 Oe を切るセルが得られた。

謝辞 本研究の一部は NEDO フォーカス 21 助成事業の一 環として行われた．また NEC-東芝で共同開発した MRAM プロセスを使用している。

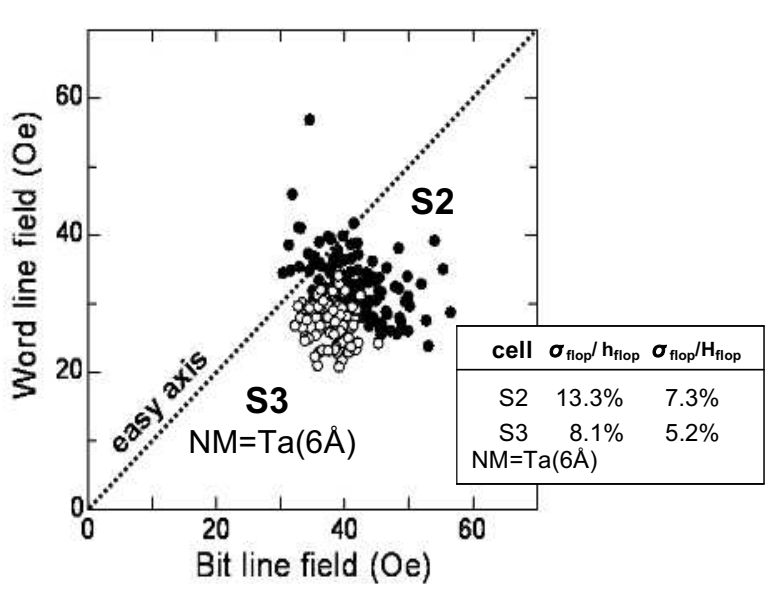

Fig. 10 Distribution of the spin-flop field for bit line and word line fields in MTJs. S2 and S3 with NM = Ta $(6 \AA)$ are indicated by the closed and open circles, respectively.

\section{References}

1) T. Miyazaki and N. Tezuka: J. Magn. Magn. Mater, 139, L231 (1995).

2) W. J. Gallagher, S. S. P. Parkin, Y. Lu, X. P. Bian, A. Marley, K. P. Roche, R. A. Altman, S. A. Rishton, C. Jahnes,

T. M. Shaw, and G. Xiao: J. Appl. Phys., 81, 3741(1997).

3) D. Gogl, et al.: Digest of Technical Papers, ISSCC. p.902 (2005).

4) Y. Iwata, et al.: Digest of Technical Papers, ISSCC. p.136 (2006).

5) M. Durlam, et al.: IEDMTechnical Digest, p.995 (2003).

6) T. Sugibayashi, et al.: IEICE Technical Report, ICD2006-12, p.61 (2006).

7) T. Sugibayashi, et al.: $A-S S C C, 11.1$ (2006).

8) M. Hosomi, et al.: IEDMTechnical Digest, p.459 (2005).

9) B. N. Engel, J. A. Janeskey, and N. D. Rizzo: US Patent No. $6,633,498 \mathrm{~B} 1$ (2003).

10) C.-C. Hung, et al.: Appl. Phys. Lett., 88, 112501 (2006).

11) D. W. Abraham and D. C. Worledge: Appl. Phys. Lett., 89, 262505 (2006).

12) J. A. Janeskey, B. N. Engel, N. D. Rizzo, and J. M. Slaughter: US Patent No. 0,120,184 A1 (2004).

13) K. Shimura, et al.: IEEE Trans. Magn., 42, 2736 (2006).

14) S. Miura, et al.: J. Magn. Magn. Mater., 310, e933 (2007).

15) H. Fujiwara, S.-Y. Wang, and M. Sun: Trans. Magn. Soc. Japan, 4, p.121 (2004).

16) Y. Fukumoto, H. Numata, K. Suemitsu, K. Nagahara, N. Ohshima, M. Amano, A. Asao, H. Hada, H. Yoda, and S. Tahara: Jpn. J. Appl. Phys., 45, No. 5A, p. 3829 (2006).

17) Y. Fukumoto, H. Honjo, C. Igarashi, T. Nagase, N. Ishiwata, S. Ikegawa, H. Yoda, and S. Tahara: IEEE Trans. Magn., 42, 2636 (2006).

18) H. -J. Kim, S. C. Oh, J. S. Bae, K. T. Nam, J. E. Lee, S. O. Park, H. S. Kim, N. I. Lee, U-In Chung, J. T. Moon, and H. K. Kang: IEEE Trans. Magn., 41, 2661 (2005).

19) T. Suzuki, Y. Fukumoto, and N. Ishiwata: J. Appl. Phys., 101, 023906-1 (2007).

20) Y. Fukumoto, T. Suzuki, and S. Tahara: Appl. Phys. Lett., 89, 061909 (2006)

21) R. Nebashi, T. Suzuki, K. Shimura, S. Saito, T. Honda, and N. Ishiwata: 30th Conference on Magnetics in Japan, 13AF-7 (2006).

22) Y. Fukumoto, et al.: J. Appl. Phys., 99, 08N905 (2006).

23) T. Suzuki, et al.: Digest of Technical Papers, Symposium on VLSI Technology, p.188 (2005).

24) iEXPO 2005, Tokyo big sight, Dec.7-9, (2005).

\section{6年10月17日受理, 2007年3月19日採録}

